\title{
Fat, Fit, and Fem: Exploring Performative Femininity for Fat Female Librarians
}

\author{
Ali Versluis, Carli Agostino, and Melanie Cassidy
}

\section{Introduction}

Fatness has been historically viewed as a mark of dehumanization and ridicule, signaling the limitation of one's intellectual, professional, and personal capabilities. ${ }^{1}$ This characterization has been particularly acute for women: fatness is seen as a detraction from their physical appearance, the main avenue through which women are expected to perform and demonstrate their femininity. Pervasive cultural narratives portray fatness as a departure from the normative female body, associating it with lack of control, ugliness, laziness, and unwillingness to conform. ${ }^{2}$ Fatness, therefore, becomes a failure to fit within the confines of femininity.

1 Marilyn Wann, "Fat studies: An invitation to revolution," in The Fat Studies Reader, ed. Esther Rothblum and Sandra Solovay (New York: New York University Press, 2009), i-iv; Nita Mary McKinley, "Ideal Weight/Ideal Women: Society Constructs the Female," in Weighty Issues: Fatness and Thinness as Social Problems, ed. Jeffrey Sobal and Donna Maurer (New Jersey: Transaction, 1999), 107; Christina Fisanick, "Evaluating the Absent Presence: The Professor's Body at Tenure and Promotion," Review of Education, Pedagogy, and Cultural Studies 28, no. 3-4 (2006): 328, doi:10.1080/10714410600873225.

2 Susan Bordo, Unbearable Weight: Feminism, Western Culture, and the Body (Berkeley: University of California Press, 1993), 195; McKinley, Ideal Weight, 107. 
With its ties to domesticity, librarianship has historically been considered a viable career path for women. During the Victorian era, white women were hired in public libraries for their inexpensive labour for the purposes of creating welcoming environments and providing gentle guidance and education to the public. ${ }^{3}$ While white women's inexpensive labour cost was welcome, the labour itself was not valued in the same way men's was. ${ }^{4}$ This devaluing of labour continues to persist in academic librarianship today: though white women are well-represented demographically within the field, the service and labour of academic librarians are rendered secondary or even tertiary within the patriarchal system of academia. Much of the labour of librarianship is emotional, relational, and associated with domesticity, leaving it at odds with the traditionally male-dominated academy.

Through this chapter, we seek to explore how service work in academic libraries - including but not limited to the realms of reference work, instruction, and committee participation-reinforces expectations of performativity for the fat female body. Moreover, we will demonstrate how fatness operates as an additional layer of oppression within a structure that is already oppressive towards women and female-coded service labour. As fatness is largely absent from the library and information science (LIS) discourse, this chapter fills a substantial gap in the research surrounding the marginalized community of fat female academic librarians. ${ }^{5}$

Collectively, we are three women who at the time of writing this chapter, worked in the same university library. As such, our professional context is primarily informed by our working experiences in various university libraries in particular and in academia in general. Among us, we identify as fat, thin, cisgender, white, queer, and heterosexual. Our context is largely what has driven us to explore this topic and has ultimately impacted our approach to and understanding of the work. Since we identify as cisgender women, we are primarily speaking from that position. However, we recognize that gender is not binary and that the issues we highlight throughout this chapter may be experienced differently for those who do not identify as male or female.

3 Dee Garrison, "The tender technicians: The feminization of public librarianship, 1876-1905," Journal of Social History 6, no. 2 (1972): 132-33, Proquest.com.

4 Garrison, “Tender Technicians”, 133.

5 While this paper focuses specifically on fat female academic librarians, we recognize that fat male academic librarians also face workplace issues and biases. However this focus falls outside of the scope of our work. 
It must also be noted that the language we use throughout this piece to refer to fat bodies is intentional. The word fat is most often applied as a negative or othering label, standing in opposition to what society defines as healthy, beautiful, and worthy. Our use of the word is a way of regaining control of it and as a form of empowerment for those who have been previously oppressed by it. Fat is a term of self-identification, which we define and apply for ourselves. Further, unlike words such as overweight and obese (which imply a negative comparison to a normative social or medical standard), fat is merely descriptive. For both clarity and means of disrupting negative social paradigms around the body, it is imperative that we use the word fat in recounting the demands put upon the body of the fat female librarian.

\section{Fatness and Femininity}

The physical body can be understood as an illustration or representation upon which our society's cultural values are inscribed. Judith Butler captured this idea in their concept of performative femininity, ${ }^{6}$ whereby they argue that bodies are the main site of gender ${ }^{7}$ construction and that one constructs their gender in accordance with the way that they perform it. ${ }^{8}$ Butler's notion of performativity posits that one's gender is assigned through performing acts and symbols which are routed in history and upheld through repetition. ${ }^{9}$ Performative acts include trivial daily behaviour such as what and how one eats, how one dresses, and how one takes up space, all of which serve to reinforce the gender rules and hierarchies of the dominant culture. ${ }^{10}$ These repetitive acts are a "strategy of survival" in a system of social pressure, with "those who fail to do their gender right [being] regularly punished." ${ }^{11}$ To put it simply, the way that one acts in public is a demonstration of how well one performs their gender.

6 Judith Butler, "Performative Acts and Gender Constitution: An Essay in Phenomenology and Feminist Theory," Theatre Journal 40, no. 4 (1988), Jstor.org; Judith Butler, Gender Trouble: Feminism and the Subversion of Identity (New York: Routledge, 1990).

7 While much of the research to date assumes a gender binary, we are aware that this is not reflective of gender in reality.

8 Butler, Gender Trouble, 164.

9 Butler, "Performative Acts", 173; Butler, Gender Trouble, 523.

10 Bordo, Unbearable Weight, 165.

11 Butler, Gender Trouble, 177-78. 
The implications of this performativity are two-fold: not only do the acts and symbols convince those around us of our gender, but they also convince us of our own gender. ${ }^{12}$ In this way, female bodies can be understood as a canvas. However, this canvas is not blank. It is a paint by numbers canvas, with each number representing a rule for the ways women's bodies must conform to the norms of their gender. When filled in (either correctly or incorrectly), the completed canvas will illustrate how well one adheres to their culture.

While both men and women are constrained socially by gender norms, the physical body holds enhanced meaning for women. Girls learn early on that they are evaluated primarily on their physical appearance and are seen as sexual and domestic prospects for men, ${ }^{13}$ resulting in a lifetime of both perpetual observance and performance. Within the contemporary Western world especially, the ideal (socially attractive) female body is heterosexual, white, middle-class, and-most importantly for our purposes-thin. ${ }^{14}$ While these characteristics once described the ideal body, they have, over time, come to represent the normal or normative body of a woman. ${ }^{15}$ The more a woman deviates from characteristics of the normative body, such as thinness, the more she moves away from the ability to be read as neutral. ${ }^{16}$

As a result of this interplay, a woman's appearance is inextricably tied to the ways that the broader culture assesses her femininity. Thus, the demands for performativity are established. In this way, thinness is directly connected to the ways in which a woman's body is expected to perform in public spaces. A thin female body takes up very little physical space, and therefore aligns with the idealized feminine qualities of being contained, small, and quiet. ${ }^{17}$ As public performers, women's bodies are viewed as something to be consumed and controlled by men. The feminine body is

12 Butler, "Performative Acts", 522.

13 McKinley, Ideal Weight, 99; Susie Orbach, Fat Is a Feminist Issue: A Self-Help Guide for Compulsive Eaters (New York: Paddington Press, 1978), 8.

14 McKinley, Ideal Weight, 103; Camille Nurka, "Moderation, reward, entitlement: The "obesity epidemic" and the gendered body," Fat Studies 3, no. 2 (2014): 166, doi:10.108 0/21604851.2014.852385.

15 McKinley, 100; Fisanick, "Evaluating the Absent", 328.

16 Bordo, Unbearable Weight, 204-5; Fisanick, "Evaluating the Absent”, 326.

17 McKinley, Ideal Weight, 99. 
one that must be watched and surveilled by broader society, ${ }^{18}$ with women being judged more harshly and with narrower margins for an "ideal weight" than men. ${ }^{19}$ They are expected to demonstrate exceptional control over their bodies, with slenderness revealing a woman's "correct management of desire." ${ }^{20}$ Thus, the body that maintains control over itself is one which performs femininity correctly. ${ }^{21}$

If the thin body is the normative body (and thus the feminine body), then the fat body must be the discordant body. If the feminine body is one that is contained physically, then the fat body is the unruly body. By "in$\operatorname{vad}[$ ing] and redefin[ing] the public sphere," 22 fat bodies become "a site of cultural contradiction and unease and as a result, are highly visible." ${ }^{23}$ If the ideal woman is supposed to be in control of her body, fat women are deviant: they do not know what is best for themselves, since they cannot maintain an ideal weight. ${ }^{24}$ Conversely, fat women also do not know what is best for others. Historically, women have been expected to perform their femininity through the feeding and nurturing of others and not themselves. ${ }^{25} \mathrm{~A}$ fat female body is seen as "greedy and excessive," ${ }^{26}$ feeding (and

18 McKinley, 98; Orbach, Fat Is, 7; Andrea N. Hunt and Tammy Rhodes. "Fat pedagogy and microaggressions: Experiences of professionals working in higher education settings," Fat Studies 7, no. 1 (2018): 27, doi.org/10.1080/21604851.2017.1360671.

19 McKinley, 100; Janna Fikkan and Esther D Rothblum. "Is Fat a Feminist Issue? Exploring the Gendered Nature of Weight Bias," Sex Roles 66, no. 9 (2012): 586, doi:10.1007/s11199-011-0022-5; Katherine Mason, "The Unequal Weight of Discrimination. Gender, Body Size, and Income Inequality," Social Problems 59, no. 3 (2012): 411-35, doi:10.1525/sp.2012.59.3.411; Behdin Nowrouzi, Alicia McDougall, Basem Gohar, Behnam Nowrouz-Kia, Jennifer Casole, and Fizza Ali, "Weight bias in the workplace: A literature review," Occupational Medicine \& Health Affairs 3, no. 3 (2015), 3, doi:10.4172/2329-6879.1000206.

20 Bordo, Unbearable Weight, 205-6.

21 McKinley, Ideal Weight, 102, 104-5.

22 Lesleigh J. Owen, "Monstrous freedom: Charting fat ambivalence," Fat Studies 4, no. 1 (2015): 6, doi:10.1080/21604851.2014.896186.

23 Amy Gullage, "An Uncomfortable Fit: Fatness, Femininity and the University," Atlantis: Critical Studies in Gender, Culture \& Social Justice 34, no. 2 (2010): 66-76, http://journals. msvu.ca/index.php?journal=atlantis\&page=article\&op=view\&path\%5B\%5D=333.

24 Hunt and Rhodes, "Fat Pedagogy", 22, 27.

25 Bordo, Unbearable Weight, 171; McKinley, Ideal Weight, 104. 
thus caring for) itself before or instead of feeding (and caring for) others. It represents "bodily desire out of control." ${ }^{27}$

Since women's bodies are those that are surveilled and consumed by broader society, thinness stands in for a form of social capital. ${ }^{28}$ Fat female bodies lack this form of social currency, putting them at a disadvantage for gaining respect and authority. As Susan Bordo notes, "the size and shape of the body have come to operate as a marker of personal, internal order (or disorder) — as a symbol for the emotional, moral, or spiritual state of the individual." ${ }^{29}$ If size and shape define a body as right or wrong, ultimately determining its social worth, how does this valuation translate into its economic worth within the workplace?

\section{Gendered Labour}

If, as Butler and Bordo have articulated, bodies are representations of culture, then bodies are also representative of an adherence to (or departure from) culture. If one examines how bodies exist in and move through academia, it becomes immediately apparent how its particular culture is overwhelmingly gendered, and how signifiers of gender (masculinity and femininity) are reinforced through the values and actions of those who work within it.

Despite the increased focus on diversity, equity, and inclusion that has recently become fashionable among Westernized institutions of higher learning, the gendered nature of the academy continues to persist. The valorization of many of the qualities the academy espouses-intellect, logic, and rationality - have tended to be qualities ascribed to men in the essentialist tradition. Therefore, it is not surprising that women, with their "natural" inclinations to emotion, feeling, and caring, were historically excluded from academia. ${ }^{30}$ The resultant structure has meant that the essence of the academy-from its structures to its spaces to its policies and priorities-has become male-coded. It is unsurprising then that the research reveals that men tend to engage with the "intellectual" activities of the

27 McKinley, Ideal Weight, 105.

28 Nurka, “Moderation”, 168.

29 Bordo, Unbearable Weight, 193.

30 Henry Etzkowitz, Carol Kemelgor, and Brian Uzzi, Athena Unbound: The Advancement of Women in Science and Technology (Cambridge: Cambridge Univ. Press, 2000), 17. 
academy: they publish more often, ${ }^{31}$ hold more financially endowed research chairs, ${ }^{32}$ and rise more quickly through the ranks. ${ }^{33}$ These accumulated levels of privilege underpin Christina Fisanick's idea that the normative body of the professoriate is "white, male, middle-class, middle-aged, able, heterosexual, and thin." ${ }^{4}$

Women are excluded from this default ideal in part by virtue of the work they do. They participate disproportionately in service-based activities such as mentoring, serving on committees, and contributing to the development of their communities. ${ }^{35}$ This participation impedes their progress through the tenure track, ${ }^{36}$ and by extension, their career. This results in a system of highly stratified gendered labour, whereby certain types of work (male-coded) are encouraged and lauded, while others (female-coded) are denigrated or outright ignored. If we consider Fisanick's conception of the normative professor, what does that mean for the staff within the academic library, who are predominantly women?

It should come as no surprise that academic libraries, as part and parcel of the university, replicate these gendered labour structures. However, unlike the university, the academic library differs in that it is

31 Sarah Theule Lubienski, Emily K. Miller, and Evthokia Stephanie Saclarides, "Sex Differences in Doctoral Student Publication Rates," Educational Researcher 47, no. 1 (2018): 76-81, doi:10.3102/0013189X17738746; Jevin D. West, Jennifer Jacquet, Molly M. King, Shelley J. Correll, Carl T. Bergstrom, "The Role of Gender in Scholarly Authorship," PLOSOne 8, no. 7 (2013), doi:10.1371/journal.pone.0066212; Vincent Larivière, Chaoqun Ni, Yves Gingras, Blaise Cronin, and Cassidy R. Sugimoto, "Bibliometrics: Global Gender Disparities in Science," Nature 504, no. 7479 (2013): 211-13. doi:10.1038/504211.

32 Katherine Side and Wendy Robbins, "Institutionalizing Inequalities in Canadian Universities: The Canada Research Chairs Program," NWSA Journal 19, no. 3 (2007): 163-81, Jstor.org.

33 Katherine Weisshaar, "Publish and Perish? An Assessment of Gender Gaps in Promotion to Tenure in Academia," Social Forces 96 no. 2 (2017): 529-60, doi:10.1093/sf/sox052.

34 Fisanick, "Evaluating the Absent", 325-26.

35 Cassandra M. Guarino and Victor M. H. Borden, "Faculty Service Loads and Gender: Are Women Taking Care of the Academic Family?” Research in Higher Education 58, no. 6 (2017): 672-94. doi:10.1007/s11162-017-9454-2.

36 Jack Grove, "Female Professors 'Pay Price for Academic Citizenship', The Times Higher Education (December 2016), https://www.timeshighereducation.com/news/femaleprofessors-pay-price-academic-citizenship; Joya Misra, Jennifer Hickes Lundquist, Elissa Holmes, and Stephanie Agiomavritis, "The Ivory Ceiling of Service Work," American Association of University Professors (January-February 2011), https://www.aaup.org/ article/ivory-ceiling-service-work. 
female-coded. While this is likely due to librarianship's history as a profession composed predominantly of women, ${ }^{37}$ it is also due to the fact that librarianship is a service-based profession. This puts the library in tension with the academy: although it exists within it, it also stands in direct opposition to it.

Even within academic librarianship—which, as a service-based profession, is feminized ${ }^{38}$ — there exists gendered expectations along labour lines. As Christine Williams points out, men who work in feminized fields tend to benefit from the "glass escalator" phenomenon, whereby they are "tracked" into roles that are more socially acceptable for their gender (which also happen to be more prestigious and better paying). ${ }^{39}$ Though Williams makes the case that male-coded work in the feminized library is managerial or administrative, a contemporary analysis would likely include the areas of information technology ${ }^{40}$ and digital scholarship. ${ }^{41}$ These growth areas are sexier and require less of the emotional labour characteristic of traditional academic librarian ${ }^{42}$ roles, such as those in public service (which often encompasses instruction and reference work).

The consequence of this division of labour is that the female-coded work (or the work expected of women) is undervalued precisely because it is done by women. This explains why instruction and reference-based roles

37 Roma M. Harris, Librarianship: The Erosion of a Woman's Profession (Norwood, NJ: Ablex Publishing Co., 1992); Shana Higgins, "Embracing the Feminization of Librarianship," in Feminists Among Us: Resistance and Advocacy in Library Leadership ed. Shirley Lew and Baharak Yousefi (Sacramento, CA: Library Juice Press, 2017), 70.

38 Higgins, Feminists Among Us; Veronica Arellano Douglas and Joanna Gadsby, "Gendered Labor and Library Instruction Coordinators" (Paper, Association of College \& Research Libraries 2017: At the Helm: Leading Transformation, Baltimore, MD, March 22-25, 2017), http:/www.ala.org/acrl/conferences/acrl2017/papers.

39 Christine L. Williams, "The Glass Escalator: Hidden Advantages for Men in the "Female” Professions," Social Problems 39 no. 3, (1992): 256, doi:10.2307/3096961.

40 Sloniowski, “Affective Labor”; Eleta Exline, "Gender Composition and Salary Gaps in Association of Research Libraries (ARL) Institutions," University of New Hampshire Master's Theses and Capstones 3 (2014): 1-118, https://scholars.unh.edu/thesis/3.

41 Mizra and Seale, "Dudes Code".

42 We use the term "academic librarians" here for simplicity's sake, however we are speaking of anyone who works in an academic library, regardless of whether they hold the title of librarian or are in possession of an MLIS or comparable degree. 
are often considered entry-level roles in academic libraries. ${ }^{43}$ These roles are often underpaid and unappreciated, ${ }^{44}$ despite the fact that they are among the most public-facing and thus require the greatest amount of emotional labour. As Kiran Mirchandani points out, there are three types of interconnected work that make up "emotion work": managing one's feeling of self, making others feel a particular way, and giving definition to one's work. ${ }^{45}$ These three types of work, which all necessitate some level of emoting with one's self, are thus all inextricably connected to performativity. Nowhere is this performativity more apparent than in service settings.

Further complicating this devaluation of female-coded labour is the challenge academic librarians face in terms of status within the academy. ${ }^{46}$ Their liminal status — not quite staff but not quite faculty — means that librarians are often denied respect, prestige, and authority as "true" academics or "real" faculty. Library director George Bennett suggested that this is because the work that librarians do is often invisible to members of their academic community. ${ }^{47}$ This work is rendered invisible because it is service-based, emotional in nature, and thus is not easily represented (and therefore valued) in a system that is preoccupied with numbers and data. Academic librarian Lisa Sloniowski writes about how challenging it is to account for entire days due to the amount of emotional labour she performs. ${ }^{48}$

43 Eamon C. Tewell, "Employment Opportunities for New Academic Librarians: Assessing the Availability of Entry Level Jobs," Libraries and the Academy 12, no. 4 (2012):

Figure 3, eamontewell.files.wordpress.com; Robert Detmering and Claudene Sproles, "Forget the Desk Job: Current Roles and Responsibilities in Entry-Level Reference Job Advertisements," College \& Research Libraries 73, no. 6 (2012): 547-49, doi.org/10.5860/ crl-304; Robert K. Reeves and Trudi Bellardo Hahn, "Job Advertisements for Recent Graduates: Advising, Curriculum, and Job-seeking Implications," Journal of Education for Library and Information Science 51, no. 2 (2010): 110-11, jstor.org.

44 Sloniowski, "Affective Labor”; Douglas and Gadsby, "Gendered Labor".

45 Kiran Mirchandani, "Challenging Racial Silences in Studies of Emotion Work: Contributions from Anti-Racist Feminist Theory," Organization Studies 24, no. 5 (June 2003): 722, doi:10.1177/0170840603024005003.

46 Harris, Librarianship; Leona Jacobs, "Academic Status for Canadian Academic Librarians: A Brief History," in In Solidarity: Academic Librarian Labour Activism and Union Activity in Canada ed. Mary Kandiuk and Jennifer Dekker (Sacramento, CA: Library Juice Press, 2014), 9-37.

47 George Bennett, Librarians in Search of Science and Identity: The Elusive Profession (Metuchen, NJ: Scarecrow Press, 1988), 173. 
The effects of this status disparity are perhaps most apparent in a teaching environment, where the librarian is treated-both implicitly and explicitly_as a guest in the classroom of a "real" faculty member. As a guest, the librarian often has only one shot to prove their worth and authority - and by extension that of the entire library - to the students in the room. This is a particularly challenging task in situations in which student attendance decreases on the day of the library session or they depart from the class mid-session. These situations signify a lack of interest on the part of all students, a damaging effect that the librarian must actively respond to and counteract throughout the remainder of their teaching.

One of the ways the librarian may attempt to gain authority or respect is by aligning herself ${ }^{49}$ with demands to perform her gender. She may do so by calling attention to and solidifying her differences fromand opposition to-the faculty member teaching the course. She will "confess" that her subject material is uninteresting and beg for attention anyway. Slidedecks will be rife with adorable pictures, animated gifs, or memes from pop culture, all used in an attempt to secure and maintain the interest of those in the room. In these ways, the librarian seeks to establish an emotional connection with the students that is more about being likable than being intelligent or authoritative, a development that has its roots in performative expectations of women providing instruction. The link between cuteness and domesticity is noted by Gina Schlesselman-Tarango, who posits that "cuteness...is itself a distinctly feminine aesthetic inasmuch as it is linked with simplicity, desexualization, infantilism, and a host of other states of supposed weakness." 50 The librarian's preoccupation with likeability and cuteness is correlated to the idea of managing one's feeling of self: she is uncomfortable with her lack of authority, so she works through this discomfort by overcompensating.

These gendered expectations and requirements for performativity are rife at the public service desk, as it is often the first point of contact between students and library staff. Throughout their time on the desk, the librarian must exhibit small acts of welcoming or attentiveness to signal to users that they are available to provide support by making eye contact,

49 We are aware that not all librarians identify as women, but we are using she/her as a shorthand both for simplicity's sake and in acknowledgement of our own lived experience as women.

50 Gina Schlesselman-Tarango, "How Cute! Race, Gender, and Neutrality in Libraries," Partnership: The Canadian Journal of Library and Information Practice and Research 12, no. 1 (2017): 4, doi:10.21083/partnership.v12i1.3850. 
smiling, and having an open posture. ${ }^{51}$ These expectations are further complicated by the fact that librarians working on the desk experience agitated or distressed students with regularity. By managing emotions, solving problems, and providing support for situations that often extend beyond the scope of the research need, this work requires librarians to assume the role of caretaker, to perform the emotional work that makes others feel a certain way. To do so, they must cultivate an image of calm approachability and effortless expertise. Portrayals of - and subsequent expectations surrounding - approachability and expertise is heightened for black, indigenous, and women of colour, who often do not have the space to express the full spectrum of emotions, lest they be characterized as angry or unprofessional.

The requirement for being simultaneously in touch with and in control of one's own emotions is heightened for women, who must perform femininity by caring for the emotions of others. Since women are approached more often at service desks, ${ }^{52}$ the potentially challenging nature of these interactions means that they must perform a disproportionate amount of acting, both at the surface and deep level. This acting is its own form of labour, which after a sustained period of time, can precipitate harmful effects, including low morale, burnout, and fatigue. ${ }^{53}$ Precisely because they are expected to perform the female-coded work of providing care more frequently than their male colleagues, women more keenly experience these damaging effects. The toll of such work is often greater for the female librarian. ${ }^{54}$

The demands to perform femininity are most acute within committee work, a cornerstone of the work performed in academic libraries. Committees and other project-based work tends to include members from across the library (and sometimes from across the institution) who work in

51 "Guidelines for Behavioral Performance of Reference and Information Service Providers," Reference \& User Services Quarterly 44, no. 1 (2004): 14-17, GaleGroup.com.

52 Jennifer L. Bonnet and Benjamin McAlexander, "Structural Diversity in Academic Libraries: A Study of Librarian Approachability," The Journal of Academic Librarianship 38, no. 5 (2012): 282-84, doi:10.1016/j.acalib.2012.06.002.

53 Miriam L. Matteson, Sharon Chittock, and David X Mease, "In Their Own Words: Stories of Emotional Labor from the Library Workforce," Library Quarterly 85 no. 1 (2015): 87, doi:10.1086/679027.

54 Miriam L. Matteson and Shelly S. Miller, "Emotional Labor in Librarianship: A Research Agenda," Library and Information Science Research 34 no. 3 (2012): 180, doi:10.1016/j.lisr2012.02.003. 
different roles with varying degrees of responsibility and autonomy. In the case of committees or projects that include members from outside the library, the librarian/faculty tension can be exacerbated and reified through the social dynamics facilitated by external parties. This dynamic can reinforce the masculine-coded nature of academia, ultimately fostering the expectation that if there is a woman in the room-or a staff member who does female-coded work - they will be assumed to perform certain tasks within the group. These tasks include such things as taking notes and providing refreshments or behaving in ways that are traditionally feminine, such as asking question ${ }^{55}$ or displaying a reluctance to interrupt or dominate the conversation. ${ }^{56}$ Contending with these expectations necessitate that women must constantly give definition to their work and contributions.

For women who do not adhere to the demands of performative femininity, there is the constant threat of both personal penalty ${ }^{57}$ and professional consequences. Expectations around performative femininity-whether implicit or explicit-in academia more generally and libraries more specifically mean that women are expected to perform increased workloads $s^{58}$ and are less likely to obtain tenure than men in similar positions. ${ }^{59}$ The demands on women to commit to high levels of emotionally laborious service roles - in other words, to uphold the dictates of societal expectations around gender-mean that women often end up with neither time nor energy to engage in some of the more "intellectual," highly valued, scholarly pursuits of their male colleagues. Ultimately, the feminization of academic libraries and the attendant expectations of performativity is deleterious for the women who work within them.

\section{Fat Women in Library Service Roles}

For fat women, these repercussions are even more significant. As within broader North American society, fatness and gender work together to compound and amplify systems of oppression that already exist within academic libraries. The fat female body is no less constrained by the dictates of

55 Pamela M. Fishman, “The Work Women Do,” Social Problems 25 no. 4 (1978): 400, Jstor.org.

56 Fiona Sheridan, "Gender, Language and the Workplace: An Exploratory Study," Women in Management Review 22, no. 4 (2007): 321-22, doi:10.1108/09649420710754264.

57 Butler, "Performative Acts", 522.

58 Douglas and Gadsby, "Gendered Labor", 270.

59 Fisanick, "Evaluating the Absent", 328. 
performativity than its thin counterpart. In fact, it is even more so due to the precise, narrow definition of femininity. Within the highly feminized academic library, there is an expectation that women perform their femininity through thinness. Fat bodies, by consequence of being not thin, are not seen as feminine or female. Precisely because the fat female body falls short of the ideal or normative body, it has to work harder to first establish femininity and eventually, personhood.

Moreover, the edicts of performativity and the preference for male-coded labour within the academic library intensify the gendered expectations of fat women, particularly those within service roles. Working in or taking on a service-focused role means an increased amount of faceto-face encounters, whether at public service desks, in one-on-one consultations, teaching a class, or working on a committee. For fat women, an increased visibility of their work (or even their mere existence) in a public space means their fatness becomes an indelible part of these interactions. It is not enough for fat women to be knowledgeable or skilled in their work. Rather, others must first notice and then move past this observation of fatness in order to acknowledge the humanity of fat women and by extension, their competence. ${ }^{60}$ To do so, each interaction must leave room for the user to mentally and emotionally "work through" the biases of laziness, stupidity, and immorality that are ascribed to fat bodies. ${ }^{61}$ In a service setting, this means repeated, continuous encounters whereby the librarian's fatness must first be observed, processed, and then set aside prior to the professional interaction beginning.

It is due to these ceaseless acts of others having to "work through" their biases in order to acknowledge the humanity of fat women that instruction work becomes especially challenging. Bias against fat women means that they are considered less intelligent or less reasoned than those with normative bodies. Even within the supposedly "enlightened" academy, there is increased stigma toward fatness. ${ }^{62}$ In the classroom, the fat librarian is confronted with anywhere from dozens to hundreds of students in a single encounter, all of whom must first notice and contend with a

60 Fisanick, "Evaluating the Absent", 326.

61 Bordo, Unbearable Weight, 193, 202.

62 Hunt and Rhodes, "Fat Pedagogy", 23; Fikkan and Rothblum, "Is Fat"; James Burford, "“Dear Obese PhD Applicants": Twitter, Tumblr and the Contested Affective Politics of Fat Doctoral Embodiment," M/C Journal, A Journal of Media and Culture 18, no. 3 (2015), http://journal.media-culture.org.au/index.php/mcjournal/article/view/969; Wann, Fat Studies Reader, xix. 
body that defies the standards of the idealized or normative female body. Regardless of any outward expression of acceptance or denial, she is subjected to the immediate surveillance and judgement of potentially hundreds of people in a single moment. This experience continues throughout the lesson as the fat librarian moves about the physical space of the room. Such movement is a living example of incongruence, as classrooms are typically designed for the normative (thin) body. Each time the fat librarian is forced to navigate physical spaces-walking down an aisle, moving between chairs, sitting in a chair, stepping out from behind a podium, or turning to face another part of the room-they are reminding the other bodies in the room of their fatness. More significantly, they are reminding themselves that they exist within a space that was not created for them and that does little to welcome them. While managing the emotions and expectations of a room full of students, the fat librarian must also manage their own feelings of not belonging. ${ }^{63}$

In these situations, the fat librarian is required to go to greater lengths to gain (or regain) authority. As mentioned earlier, academia ascribes traits of intelligence, confidence, and competency to normative (male) bodies. In the case of women, who are already one step removed from that normative male body, demonstrating fitness to teach a class means adhering to normative female body standards as much as possible. Fisanick traces the parallels between the mind/body dichotomy and the male/female dichotomy, with men being traditionally associated with the mind and women with the body. ${ }^{64}$ Therefore, it follows that the more closely one adheres to normative body standards, the more others around them can look past their body to consider the mind.

To more closely align with these normative standards, women are more likely to attempt to make their body "invisible" by embracing performative elements in the hope that some semblance of authority will be conferred upon them. The fat female librarian may go to greater lengths to establish her womanhood by wearing feminine clothing and makeup, by conforming to stereotypes such as being soft-spoken and gentle, being eternally optimistic and upbeat, or being explicit about her willingness to support and care for those in the room (e.g. reminding students how much she loves to help, smiling reassuringly). This increased effort to

63 Gullage, "Uncomfortable Fit"; Ashley Hetrick and Derek Attig, "Sitting pretty: Fat Bodies, Classroom Desks, and Academic Excess," in The Fat Studies Reader, ed. Esther Rothblum and Sandra Solovay (New York: New York University Press, 2009). 
deliver emotional labour can lead to an increased mental and emotional load, which can exacerbate burnout and mental health issues. ${ }^{65}$

The structural cues that reinforce notions of not belonging persist beyond the classroom. The surveillance of the female body within public spaces is a phenomenon that is amplified for fat women, who often report feeling over-monitored in public settings. ${ }^{66}$ Public service desks are ideal environments for the hyper monitoring of fat women, who must contend with repeated encounters in which the observe-consider-continue pattern-necessary for the assessment of personhood—continues throughout the day in perpetuity. Moreover, working at a public service desk means contending with a constant reminder that one exists within a space intended for normative bodies. Chairs, particularly those with arm rests, are often too narrow for a range of bodies to sit in comfortably, ${ }^{67}$ something that is likely noticed by both library users and colleagues. If no chair is provided, the librarian must stand, often for extended periods of time. If observed by others, those much-needed moments of rest or of leaning on a desk may reinforce characterizations of fat women as lazy and unkempt. ${ }^{68}$ The fat female librarian must sit or stand in discomfort while continuously performing emotional labour for users, a discomfort that is readily apparent to observers due to its physical manifestation (regardless of whether they decide to approach the service desk). Much like within the classroom, expectations around the fat female body mean that the librarian must overperform the welcoming, emotive gestures expected of women in service roles, all in the hopes that she will be perceived as equally as welcoming as those with normative bodies.

65 Mary Ann Affleck, "Burnout Among Bibliographic Instruction Librarians," Library and Information Science Research 18, no. 2 (1996): 165-83, doi:10.1016/S07408188(96)90018-3; Janette S. Caputo, Stress and Burnout in Library Service (Phoenix, AZ: Oryx Press, 1991); Da-Yee Jeung, Changsoo Kim, and Sei-Jin Chang, "Emotional Labor and Burnout: A Review of the Literature, "Yonsei Medical Journal 59, no. 2 (2018): 187-93, doi:10.3349/ymj.2018.59.2.18; Deborah F. Sheesley, "Burnout and the Academic Teaching Librarian: An Examination of the Problem and Suggested Solutions," The Journal of Academic Librarianship 27, no. 6 (2001): 447-51, doi:10.1016/ S0099-1333(01)00264-6.

66 Irmgard Tischner and Helen Malson, "Exploring the Politics of Women's In/Visible 'Large' Bodies," Feminism \& Psychology 18, no. 2 (2008): 264, doi:10.1177/095935350 7083096.

67 Gullage, "Uncomfortable Fit”, 71. 
It is unsurprising then that fat women in the workplace face increased difficulties both in terms of earning the authority and respect of their colleagues, as well as maintaining that authority and respect. ${ }^{69}$ In committee and other project-based work, fat women must contend with the biases and judgements already formed by colleagues and peers, then work harder to mitigate those biases by managing the emotions of those at the table. The caregiving and acts of restraint expected of women who serve on academic committees is in greater demand for fat women, who face an increased threat of punitive responses from colleagues and superiors. ${ }^{70}$ This may precipitate taking on an increased workload in order to be seen to match the efforts of others or an increased pressure to accept less desirable or less visible roles within the committee. In cases where the fat female librarian is occupying a chair position, this can also mean increased effort put into directing the work of the committee, since her directives and decisions may be ignored or undermined.

For the female librarian who fails to perform gender appropriately, there is at least the reassurance of neutrality that comes from inhabiting a normative or ideal (slender) body. ${ }^{71}$ This neutrality is lacking for the fat female librarian, whose body_-simply by existing — signals a deviance from societal norms and expectations around gender. ${ }^{72}$ Librarians have been historically associated with quietness, organization, and containment: all elements which a fat body supposedly contradicts. A fat body is loud and uncontained: it exudes presence. Thus, for the fat female librarian on a committee, expressing either a firm opinion or dissent is a double-edged sword. She will suffer from both the characterization of women as shrill and bossy as well as the judgement that she is unorganized or incapable of making rational decisions. ${ }^{73}$

In every instance of service work, the fat female librarian is subjected to additional layers of pressure and an increased threat of penalty. Any failure to establish femininity (and by extension, personhood) carries the

69 Mason, "Unequal Weight”, 431-32.

70 Fisanick, "Evaluating the Absent”, 328-29; Fisanick, "They Are”, 244-45; Mason, "Unequal Weight”, 431-33; Fikkan and Rothblum, "Is Fat”, 578-79; Butler,

"Performative Acts", 522; Butler, Gender Trouble, 177-78.

71 A female body does not necessarily mean that you are a woman, but this is a societal shortcut people take.

72 Owen, "Monstrous Freedom", 8.

73 Hunt and Rhodes, "Fat Pedagogy", 26. 
very real risk of repercussions, which can be personal and/or professional. It comes as no surprise then that fat people encounter difficulties obtaining employment, ${ }^{74}$ and are more likely to face income inequality, a consequence that is greatly amplified for fat women. ${ }^{75}$ Even once employment is obtained, fat women are less likely to receive positive performance reviews than their male or normative-bodied female counterparts ${ }^{76}$ and are paid lower salaries. ${ }^{77}$ Within the academy, fat women are more likely to be seen as lacking in self-control, a characterization that they attempt to counteract by overperforming and taking on additional work. ${ }^{78}$

This implicit bias has worrisome implications for the progression of the fat body through the tenure and promotion process, a system that is inherently problematic due to its valorization of overwork and characteristic gender discrimination. ${ }^{79}$ As with other systemic biases, the culpability for weight-based discrimination is almost always attributed to the individual (often the fat person), rather than being recognized as a widespread problem endemic to the institution, its attendant processes, and structure. U1timately, the weight of navigating and overcoming these myriad levels of oppression lies on the fat person.

\section{Recommendations for Change and Future Research}

The body is gendered and the implications of this gendering are significantly more pronounced for women than they are for men..$^{80}$ Body size is one of the primary ways in which women are seen as feminine, with fatness

74 Nowrouzki et. al, "Weight Bias"; Jens Agerstrom and Dan-Olof Rooth, "The Role of Automatic Obesity Stereotypes in Real Hiring Discrimination," Journal of Applied Psychology 96, no. 4 (2011): 790-805, doi:10.1037/a0021594; Sharon Grant and Toby Mizzi, "Body Weight Bias in Hiring Decisions: Identifying Explanatory Mechanisms," 42, no. 3 (2014): 353-70, doi:10.2224/sbp.2014.42.3.353.

75 Fikkan and Rothblum, "Is Fat", 17; Mason, "Unequal Weight".

76 Fikkan and Rothblum, "Is Fat", 19.

77 Mason, "Unequal Weight”, 431.

78 Hunt and Rhodes, "Fat Pedagogy", 23.

79 Fisanick, "Evaluating the Absent"; Christina Fisanick, "'They Are Weighted with Authority": Fat Female Professors in Academic and Popular Cultures," Feminist Teacher 17, no. 3 (2007): 237-55, Jstor.org. Bordo, Unbearable Weight; Butler, Gender Trouble. 
being regarded as a failure to perform femininity appropriately. ${ }^{81}$ Within the context of the academic library, the demands for gender performativity become ever greater, as the body exists within a female-populated environment that sits within the male-coded academic sphere. Women in academic libraries are expected to perform the female-coded work of providing care and nurturing, while simultaneously receiving pressure to remain competitive in accomplishing male-coded work, that which signals seriousness. ${ }^{82}$ For fat female librarians, the expectations around how and to what degree femininity must be performed are heightened in a service setting due to the simultaneous invisibility and hyper-surveillance fat women experience. ${ }^{83}$ Any failure to adhere to systemic and individual expectations of performativity — no matter how minute — often results in difficulty finding employment, inability to obtain tenure, and/or reduced compensation. ${ }^{84}$

As mentioned earlier, the scholarship that speaks to the intersection of fatness and librarianship is almost non-existent. This chapter fulfills an important role in contributing to the scholarship on fatness, gender performativity in library service roles, and the ways in which the two intersect to create additional layers of oppression for fat female librarians. If increased labour is expected both of fat women in society, and of all women in libraries, then the amount of labour (both emotional and otherwise) expected of fat women is unconscionable.

Overall, attitudes and behaviour stemming from fat bias, as well as those that inform and reinforce patriarchal power structures, must be addressed in order to ensure that fat women in libraries do not suffer undue burden to prove their worth and value on a daily basis. To remedy this, bias toward fat people-and fat women in particular-must be included in inclusivity and implicit bias training. Library and university staff should be encouraged and expected to voice opposition to expression of discrimination towards fat people. Staff at all levels-but especially those in management or positions of authority — should receive training on how to approach topics of fatness from a politically-informed and critical perspective, as opposed to one that is focused on weight reduction (or those that use "health" as a codeword for thinness).

81 Bordo, Unbearable Weight, 204; Nurka, "Moderation”, 168.

82 Douglas and Gadsby, "Gendered Labor", 268.

83 Hunt and Rhodes, "Fat Pedagogy", 27; Mckinley, Ideal Weight, 98.

84 Fikkan and Rothblum, "Is Fat", 17; Fisanick, "Evaluating the Absent"; Fisanick, "They Are"; Mason, "Unequal Weight". 
This work is just the beginning of an examination of how fat women are met with increased expectations via their adherence to or departure from performative femininity. Future areas of research should examine how other historically disenfranchised identities figure into the intersection of fatness and libraries. How does race, ethnicity, sexual orientation, gender identity or expression, disability, or other socioeconomically marginalized identities impact expectations and treatment of fat librarians? A closer look could be paid to fat female librarians in non-service roles or those who occupy positions of authority or management to ascertain how or if such positionality is affected. Although there has been some work done on fatness in academic spaces, ${ }^{85}$ bringing additional library-focused perspectives would allow the scholarship in this area to be more fulsome. Lastly, empirical research focusing on the lived experiences of fat women in libraries or studies containing current data would be of great import to scholarship in the areas of fat studies and library and information studies. However, the importance of contributing to these conversations extends beyond libraries or higher education. This research contributes to a shift in social perspectives that includes fat women, a necessary step to take if we are to improve diversity and inclusion within libraries and more equitable treatment of fat women in general.

85 Fisanick, "Evaluating the Absent"; Fisanick, "They Are"; Gullage, "Uncomfortable Fit"; Corey Stevens, "Fat on Campus: Fat College Students and Hyper(in)visible Stigma," Sociological Focus, 51 no. 2 (2018): 130-49, doi:10.1080/00380237.2017.13688839. 
Deconstructing Service in Libraries

Veronica Arellano Douglas and Joanna Gadsby

\section{Bibliography}

Affleck, Mary Ann. "Burnout among Bibliographic Instruction Librarians." Library and Information Science Research 18, no. 2 (1996): 165-83. doi:10.1016/ S0740-8188(96)90018-3.

Agerstrom, Jens, and Dan-Olof Rooth. "The Role of Automatic Obesity Stereotypes in Real Hiring Discrimination." Journal of Applied Psychology 96, no. 4 (2011): 790-805. doi:10.1037/a0021594.

Bennett, George. Librarians in Search of Science and Identity: The Elusive Profession. Metuchen, NJ: Scarecrow Press, 1988.

Bonnet, Jennifer L., and Benjamin McAlexander. "Structural Diversity in Academic Libraries: A Study of Librarian Approachability." The Journal of Academic Librarianship 38, no. 5 (2012): 277-86. doi:10.1016/j.acalib.2012.06.002.

Bordo, Susan. Unbearable Weight: Feminism, Western Culture. Berkeley: University of California Press, 1993.

Butler, Judith. "Performative Acts and Gender Constitution: An Essay in Phenomenology and Feminist Theory." Theatre Journal 40, no. 4 (1988): 519-31. Jstor.org.

---. Gender Trouble: Feminism and the Subversion of Identity. New York: Routledge, 1990.

Burford, James. ““Dear Obese PhD Applicants”: Twitter, Tumblr and the Contested Affective Politics of Fat Doctoral Embodiment." M/C Journal, A Journal of Media and Culture 18, no. 3 (2015). http://journal.media-culture.org.au/ index.php/mcjournal/article/view/969.

Caputo, Janette S. Stress and Burnout in Library Service. Phoenix, AZ: Oryx Press, 1991.

Detmering, Robert, and Claudene Sproles. "Forget the Desk Job: Current Roles and Responsibilities in Entry-Level Reference Job Advertisements." College \& Research Libraries 73, no. 6 (2012): 543-55. doi.org/10.5860/crl-304.

Douglas, Veronica Arellano, and Joanna Gadsby. "Gendered Labor and Library Instruction Coordinators." Paper presented at the Association of College \& Research Libraries 2017: At the Helm: Leading Transformation, Baltimore, MD, March 22-25, 2017. American Library Association, http://www.ala.org/acrl/conferences/acrl2017/papers.

Etzkowitz, Henry, Carol Kemelgor, and Brian Uzzi. Athena Unbound: The Advancement of Women in Science and Technology. Cambridge: Cambridge Univ. Press, 2000.

Exline, Eleta, "Gender Composition and Salary Gaps in Association of Research Libraries (ARL) Institutions." University of New Hampshire Master's Theses and Capstones 3 (2014): 1-118. https://scholars.unh.edu/thesis/3.

Fikkan, Janna, and Esther D. Rothblum. "Is Fat a Feminist Issue? Exploring the Gendered Nature of Weight Bias." Sex Roles 66, no. 9 (2012): 575-92. doi:10.1007/s11199-011-0022-5. 
Fisanick, Christina. "Evaluating the Absent Presence: The Professor's Body at Tenure and Promotion." Review of Education, Pedagogy, and Cultural Studies 28, no. 3-4 (2006): 325-38. doi:10.1080/10714410600873225.

---. ""They Are Weighted with Authority": Fat Female Professors in Academic and Popular Cultures." Feminist Teacher 17, no. 3 (2007): 237-55. Jstor.org.

Fishman, Pamela M. “The Work Women Do." Social Problems 25 no. 4 (1978): 397-406. Jstor.org.

Garrison, Dee. "The tender technicians: The feminization of public librarianship, 1876-1905." Journal of Social History 6, no. 2 (1972): 131-59. Proquest.com.

Grant, Sharon, and Toby Mizzi. "Body Weight Bias in Hiring Decisions: Identifying Explanatory Mechanisms." 42, no. 3 (2014): 353-70. doi:10.2224/ sbp.2014.42.3.353.

Guarino, Cassandra M., and Victor M. H. Borden. "Faculty Service Loads and Gender: Are Women Taking Care of the Academic Family?" Research in Higher Education 58, no. 6 (2017): 672-94. doi:10.1007/s11162-017-9454-2.

"Guidelines for Behavioral Performance of Reference and Information Service Providers." Reference \& User Services Quarterly 44, no. 1 (Fall 2004): 14-17. GaleGroup.com.

Gullage, Amy. "An Uncomfortable Fit: Fatness, Femininity and the University." Atlantis: Critical Studies in Gender, Culture \& Social Justice 34, no. 2 (2010): 66-76. http://journals.msvu.ca/index. php?journal=atlantis\&page=article\&op=view \&path\%5B\%5D=333 .

Grove, Jack. "Female Professors ‘Pay Price for Academic Citizenship'." The Times Higher Education (December 2016). https://www.timeshighereducation. com/news/female-professors-pay-price-academic-citizenship.

Harris, Roma M. Librarianship: The Erosion of a Woman's Profession. Norwood, NJ: Ablex Publishing Co., 1992.

Hetrick, Ashley, and Derek Attig. "Sitting pretty: Fat bodies, Classroom Desks, and Academic Excess." In The Fat Studies Reader, edited by Esther Rothblum and Sandra Solovay, 197-204. New York: New York University Press, 2009.

Higgins, Shana. "In Feminists Among Us: Resistance and Advocacy in Library Leadership." In Embracing the Feminization of Librarianship, edited by Shirley Lew and Baharak Yousefi, 67-89. Sacramento, CA: Library Juice Press, 2017.

Hunt, Andrea N., and Tammy Rhodes. "Fat Pedagogy and Microaggressions: Experiences of Professionals Working in Higher Education Settings." Fat Studies 7, no. 1 (2018): 21-32. doi.org/10.1080/21604851.2017.1360671.

Jacobs, Leona. "Academic Status for Canadian Academic Librarians: A Brief History." In In Solidarity: Academic Librarian Labour Activism and Union Activity in Canada, edited by Mary Kandiuk and Jennifer Dekker, 9-37. Sacramento, CA: Library Juice Press, 2014.

Jeung, Da-Yee, Changsoo Kim, and Sei-Jin Chang. "Emotional Labor and Burnout: A Review of the Literature." Yonsei Medical Journal 59, no. 2 (2018): 187-93. doi:10.3349/ymj.2018.59.2.187. 
Deconstructing Service in Libraries

Veronica Arellano Douglas and Joanna Gadsby

Larivière, Vincent, Chaoqun Ni, Yves Gingras, Blaise Cronin, and Cassidy R. Sugimoto. "Bibliometrics: Global Gender Disparities in Science." Nature 504, no. 7479 (2013): 211-13. doi:10.1038/504211a.

Lubienski, Sarah Theule, Emily K. Miller, and Evthokia Stephanie Saclarides. "Sex Differences in Doctoral Student Publication Rates." Educational Researcher 47, no. 1 (January 2018): 76-81. doi:10.3102/0013189X17738746.

Mason, Katherine. "The Unequal Weight of Discrimination. Gender, Body Size, and Income Inequality." Social Problems 59, no. 3 (2012): 411-35. doi:10.1525/sp.2012.59.3.411.

Matteson, Miriam L., Sharon Chittock, and David X Mease. "In Their Own Words: Stories of Emotional Labor from the Library Workforce." Library Quarterly 85 no. 1 (2015): 85-105. doi:10.1086/679027.

Matteson, Miriam L., and Shelly S. Miller. "Emotional Labor in Librarianship: A Research Agenda." Library and Information Science Research 34, no. 3 (2012): 176-83. doi:10.1016/j.lisr2012.02.003.

McKinley, Nita Mary. "Ideal Weight/Ideal Women: Society Constructs the Female." In Weighty Issues: Fatness and Thinness as Social Problems, edited by Jeffrey Sobal and Donna Maurer, 97-115. New Jersey: Transaction, 1999.

Mirchandani, Kiran. "Challenging Racial Silences in Studies of Emotion Work: Contributions from Anti-Racist Feminist Theory." Organization Studies 24, no. 5 (June 2003): 721-42. doi:10.1177/0170840603024005003.

Misra, Joya, Jennifer Hickes Lundquist, Elissa Holmes, and Stephanie Agiomavritis. "The Ivory Ceiling of Service Work." American Association of University Professors (January-February 2011). https://www.aaup.org/article/ivoryceiling-service-work\#.XE-vEJNKiAy.

Mizra, Rafia, and Maura Seale. "Dudes Code, Ladies Coordinate: Gendered Labor in Digital Scholarship." Presentation, Digital Library Forum, Pittsburgh, PA, October 23-25, 2017.

Nowrouzi, Behdin, Alicia McDougall, Basem Gohar, Behnam Nowrouz-Kia, Jennifer Casole, and Fizza Ali. "Weight bias in the workplace: A literature review." Occupational Medicine \& Health Affairs 3, no. 3 (2015): 1-10. doi:10.4172/2329-6879.1000206.

Nurka, Camille. "Moderation, reward, entitlement: The "obesity epidemic" and the gendered body." Fat Studies 3, no. 2 (2014): 166-78. doi:10.1080/21604851.2 014.852385.

Orbach, Susie. Fat Is a Feminist Issue: A Self-Help Guide for Compulsive Eaters. New York: Paddington Press, 1978.

Owen, Lesleigh J. “Monstrous freedom: Charting fat ambivalence." Fat Studies 4, no. 1 (2015): 1-13. doi:10.1080/21604851.2014.896186.

Sheesley, Deborah F. "Burnout and the Academic Teaching Librarian: An Examination of the Problem and Suggested Solutions." The Journal of Academic Librarianship 27, no. 6 (2001): 447-51. doi:10.1016/ S0099-1333(01)00264-6. 
Sheridan, Fiona. "Gender, Language and the Workplace: An Exploratory Study." Women in Management Review 22, no. 4 (2007): 319-36. doi:10.1108/09649420710754264.

Reeves, Robert K. and Trudi Bellardo Hahn. "Job Advertisements for Recent Graduates: Advising, Curriculum, and Job-seeking Implications." Journal of Education for Library and Information Science 51, no. 2 (2010): 103-19, jstor.org.

Roxanne Shirazi. "Reproducing the Academy: Librarians and the Question of Service in the Digital Humanities." Roxanne Shirazi (blog), 2014.

Side, Katherine, and Wendy Robbins. "Institutionalizing Inequalities in Canadian Universities: The Canada Research Chairs Program." NWSA Journal 19, no. 3 (2007): 163-81. Jstor.org.

Simon, Jane. "The construction of femininity in discourses of the woman librarian: 1890 s to 1940s." The Australian Library Journal 43, no. 4 (1994): 257-71. doi. org/10.1080/00049670.1994.10755696.

Sloniowski, Lisa. "Affective Labor, Resistance, and the Academic Librarian." Library Trends 64, no. 4 (2016): 645-66. doi:10.1353/lib.2016.0013.

Stevens, Corey. "Fat on Campus: Fat College Students and Hyper(in)visible Stigma." Sociological Focus 51, no. 2 (2018): 130-49. doi:10.1080/00380237.2 017.13688839.

Schlesselman-Tarango, Gina. “How Cute! Race, Gender, and Neutrality in Libraries." Partnership: The Canadian Journal of Library and Information Practice and Research 12, no. 1 (2017): 1-19. doi:10.21083/partnership. v12i1.3850.

Tewell, Eamon C. "Employment Opportunities for New Academic Librarians: Assessing the Availability of Entry Level Jobs." Libraries and the Academy 12, no. 4 (2012): 407-23. eamontewell.files.wordpress.com.

Tischner, Irmgard, and Helen Malson. "Exploring the Politics of Women's In/ Visible 'Large' Bodies." Feminism \& Psychology 18, no. 2 (2008): 260-67. doi:10.1177/0959353507083096.

Wann, Marilyn. "Fat studies: An invitation to revolution." In The Fat Studies Reader, edited by Esther Rothblum and Sandra Solovay, ix-xxv. New York: New York University Press, 2009.

Weisshaar, Katherine. "Publish and Perish? An Assessment of Gender Gaps in Promotion to Tenure in Academia." Social Forces 96 no. 2 (2017): 529-60. doi:10.1093/sf/sox052.

West, Jevin D., Jennifer Jacquet, Molly M. King, Shelley J. Correll, Carl T. Bergstrom. "The Role of Gender in Scholarly Authorship." PLOSOne 8, no. 7 (2013): doi:/10.1371/journal.pone.0066212.

Williams, Christine L. "The Glass Escalator: Hidden Advantages for Men in the "Female" Professions." Social Problems 39 no. 3 (1992): 253-67. doi:10.2307/3096961. 